\title{
The Classification and Preferences of Electronic Dictionaries in Modern Education
}

\author{
Zhala Mammadova \\ National Academy of Sciences of Azerbaijan, Republic of Azerbaijan, Linguistics Institute (Ph.d student)
}

\begin{abstract}
The article deals with different approaches to the understanding of essence of e-dictionaries and their classification. Much attention is directed to the functions and structural features of traditional and e-dictionaries, besides using them in teaching process. Systematization of search techniques in electronic dictionaries would favor the teaching and learning process, and could also facilitate the task of lexicographers and terminology-graphics in the creation of new and more standardized electronic dictionaries.
\end{abstract}

Keywords: electronic dictionary, search technology, teaching process, hyperlinks, wikipedia, computer lexicography

\section{Introduction}

The modern education develops in the condition of information technology integration. Speedy development of new information technology influences to the formation personality of modern school pupils. School is the part of the society, all problems which happened in the world reflects from there. Training process must organise by amateurly so pupils participate active in this process. In the solution of such kind of complex problems teachers are supported by traditional training methods integrates with modern information technology, at the same time lesson models planned by computers. Using electronic dictionary in during teaching process is development and here the lesson can be interesting. Everybody's attention is directed to the board. To attract much attention depends on the designs of edictionaries. While translating any text the students can hear the pronunciation of any words and see different phrases connects with searching words. These multimedia, audiovideo dictionaries are modern in teaching. We can make some special hyperlinks on the translated text. So, we make connection with some e-dictionaries directly. After all, there is no need to search unknown words in any e-dictionaries; link is transferred to direct address by the help of active hyperlinks. The results are appeared at once. If we say the modern training process it means using special technical information apparatus, for example, Electron Counting Machines (ECM), audio, video, films and etc. According to the pedagogical problems information Communication Technology (ICT) has own training means. One of them is Assistant aids - (encyclopedias, electronic dictionaries, multimedia study training) [5]

Dictionary is the words collection of lined up in alphabetically, giving the meaning or the translation. If the dictionaries has practical character they reflects in the development of literature theory and turned out scientific normative. Beginning of every root is standing history. The history of dictionaries is very ancient. Either the East and or the West dictionaries have ancient histories. The first Turkish dictionary Divani lugat it-turk was written by great Turkish scholar Mahmud Kashgari in Bagdad in 1072-1074. This dictionary is rich with wisdom words, poems and prose samples. Dictionary consists of eight chapters and was written in according with the rules of Arabic language. It's kept in Istanbul National Library. Thus, studying the history of dictionaries doesn't include to my investigation, but I dare to stress it shortly for comparing the new generation dictionaries with old. Global Internet influences to the lexicograpy, and reimburses all needs of society with its technical opportunities. For improving dictionaries domination of E-dictionaries in the internet is caused the interesting of modern linguistic. Keeping additional information, these dictionaries have inner using ability even it's possible to leave for here with anonym comments. Lexicography lives its new stage in its development way now. Electronic dictionaries include new search capabilities, not found in traditional dictionaries that could meet users needs. However, the diversity of search options in electronic dictionaries makes their classification difficult, and consequently hinders training in their use. The development computers, communication and multimedia technology created a new generation in lexicography, and also the lexical resources appointed new opportunities for development global net. Lexicography is one of the ancient field of linguistics, which engages the problems of different volume dictionaries. According to general characters division of the dictionaries have been reflected as following.

\section{1)Encyclopedic dictionaries - Soviet encyclopedy,} Literature encyclopedy, Linguistics encyclopedy, Pedagogical encyclopedy, Children encyclopedy and etc...

2)Unilingual dictionaries-Terminology dictionary, Ethimology dictionary, Explanatory dictionary, Synonyms Antonyms dictionary, Omonyms dictionary, Phraselogical dictionary, Orthography dictionary and etc...

3)Monolingual dictionaries - translation dictionaries Russian-Azerbaijan-English, Russian-German-Azerbaijan, English-Russian-Azerbaijan and etc...[1.12-15]

According to prof. M. Mahmudov all operations realizing in electronic dictionaries are appeared by the superiority of computers technology. It is possible to realize the grouping of the words, lining its alphabetically in computer in a short time. Dictionary editors as lexicographer must do their works in a high quality. (Especially the words translation and explanation must be given correctly and etc.). The main purpose is to locate those dictionaries in internet. It's obviously clear that the computers help the dictionary editors 


\section{International Journal of Science and Research (IJSR) \\ ISSN (Online): 2319-7064}

Index Copernicus Value (2013): 6.14 | Impact Factor (2015): 6.391

in two aims: speeding up compile the dictionary and locating their in internet. [7.78-79]

Dictionaries play a great role in the people's life. The main basical tool for phylologist, translators, teachers and students is dictionary. The development of computers, communications and multimedia technologies is creating new lexicographic resourses for new generations. Many years ago, we spent much time for finding the meaning of the words but just now it's so easy, we do it rapidly by the help of internet dictionaries. Computer technology and the modern computers can help to lexicographers in this level. But we meet different problems here. Sometimes we meet such kind of dictionaries which are located on internet as traditional dictionaries, but using these dictionaries is the same as print dictionaries. Just simply we look the words via the screen and we waste much time for finding the meanings of the worlds. f.ex. 1.Musayev Oruj - English-Azerbaijan dictionary (130 000 words) Baki, Gismet Press 2008. /library.adau.edu.az 2.Hasrat HasanovAntonyms dictionary of Azerbaijan language. Baki, Azer Press, $1985 \quad$ /turuz.com/kitaplar/sozluk 3.The Comprehensive English-Russian Scientific and Technical Dictionary. (200000) Moscow 1991, 702 p. / www.amazon.com/references and etc..

Basing on P. Sharp's opinions, the copying traditional dictionaries on the computers originally is almost as the same as the usage of the dictionary book and it hasn't any prospectively. But N. Forget proved that electronic dictionaries differ from print dictionaries for their usage: presentation, search opportunity, technical aspects, inner forms (multimedia elements) \& etc. He considers the using hypertext in electron dictionary, N. Forget also emphasized that every electronic dictionary has its inner form, and finally every user must spend more time for learning inner instructions of these electronic dictionaries. [4.3-4] Electronic dictionaries are controlled by special program systems. According to the queries the e-dictionaries were controlled, the words standing with alphabet systematically, marking process occurs and the explanation of word is introduced automatically to the users attention. All edictionaries havn't the same functions. Each of them has got various functions.

Recently, in the direction of lexicographic studing have considerable development. According to prof. G.R.Chumarina the phenomenon of "Electronic dictionary" have been created lately. A lot of investigations have been studing arround this field. At the present moment the new terms "electronic dictionaries" and "dictionaries in electronic conveyers" have been separeted in the language. Dictionaries on compact CD disk hold a large place and using from these are the same as traditional dictionaries. The differences of electronic dictionaries from traditional dictionaries are: introducing, tehnical functions, technical aspects, multimedia elements, pictures, sounds, animations and short video roliks etc. It's possible to search the words in electronic dictionaries by alphabetically, lexics units and sound system. It improves in appearance of lexica's esthetic view, the working atmosphere becomes lighter, each users fell comfort here. The special orthoepic corrector controls system exisisting in these types of e-dictionaries. It is necessary having such kind of elements language. Obviously it's clear that, the print dictionaries have not these indigators (abilities). E-dictionaries can be analyzed as follows:

- What is the strongest and the weakest side of edictionaries?

- What is the differences between e-dictionaries and traditional dictionaries?

- Which priorities and defficiencies have e-dictionaries?

- How to improve e-dictionaries for the next generation? [2,265-270]

\section{*Priorities of e-dictionaries:}

Memory functions, more hyper texts, different additional information, rapidly, effectively, illustrative, short fragmental, video-rolics, having many functions and opportunities but held a very little place in the library, it's possible to print explanation of any words \& etc...

\section{*Deficiency of e-dictionaries:}

Interface of e-dictionaries are distinctive. All e-dictionaries demand teaching period. Searching is limited. Lack of information caused wasting time. More advertisements, no hyperlinks \& etc...

Heming Borgenholtz noted that "If electronic dictionaries allow speedly search potentially, it depends on their arrangement, electronic press runs us away worries" " $[3,28]$ Dictionaries are classified on the basis of majority of the languages. They don't consist of wide choice of the words they have focused on the function of general usage of lexical unique. At the present the modern readers respect the usage Internet for the getting the most operative information.

The concept of the dictionary have modified progressively by the help of development of new technologies and the Internet. Many traditional dictionaries have been converted to electronic formats, such as CD-ROM, some are presented to users in online forms. E-dictionaries can be analysed in diferent based on various criterias. The typology of edictionaries was explained by Lehr. He based on technical evaluation, this author distinguishes between online or offline dictionaries. Offline dictionaries comprise pocket electronic dictionaries (PEDs) and PC dictionaries (PCD). PCD includes the dictionaries in CD-ROM, floppy disk and other formats. Based on lexicographic evaluation, this typology distinguishes between electronic dictionaries based on their paper versions, and newly developed electronic dictionaries, as well as electronic dictionaries with both print and innovative appearances. [4, 7-9]

1. Merriam Webster Dictionary - Utilization more than 150 years, unilingual explanatory e-dictionary. The words are lining with alphabet automatically. In search panel the word Furniture" is searched. Introducing explanation is significant Figure 1. But the phonetics symbol of this word isn't correct. [f3:nitfo]. Besides, the examples refer to this word is few. Dictionary can introduce the archaic variants of searching words.

2.

\section{Volume 5 Issue 7, July 2016} www.ijsr.net 

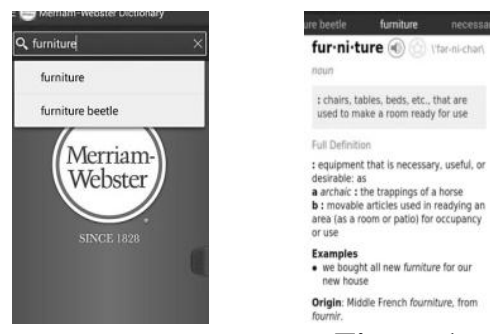

Figure 1

Merriam Webster has many different functions. As we look above: Recommended apps, feedback, share this app, about and etc... we can use this e-app in the teaching process easily. The online version of Merriam Webster's Advanced Leaner's English Dictionary, which has had the feature ever since it was launched, offers search suggestions already at the initial letter. [8]

2. Ultralingua website - We can meet a lot of meanings of searching words. As we can see in the Figure 2, the word Played" is searched. The word was entered in suffixes form in searching bloc. Thus, e-dictionary knew this word and introduse the all variants (without infinitive, the root of words) of this word to user's attention. Explanation is given significantly (with samples, synonyms, phraseological units, word combinations). [9]

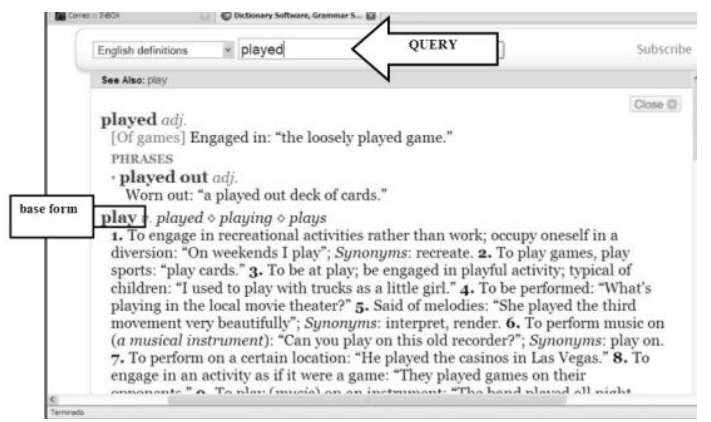

Figure 2

The object of investigation is a word, but predimet is to give all meanings of the words in new formats in electronic resourse system. It has been determined that importance of this kind of words reflect languages and culture in connections. The most popular free universal encyclopedia in internet is Wikipedia. The base of Wikipedia organizes Wiki Technology. It's non-commercial website. This website makes possibility using, editing and presenting scientific articles even to edit another user's articles. Wikitionary - is the collection of explanation articles, thesaurus and grammatical dictionary. There are many Russian, English, German, French, Polish, Malaysian, Chins, and Latvia dictionaries in this website. The explanation of the words, pronunciation rules, speech patterns are shown in these dictionaries. [6]

3. Macmillan English Dictionary Online - is more advanced use of functionality. During the searching process after typing the second element of search term here pulldown suggested items lists opens.

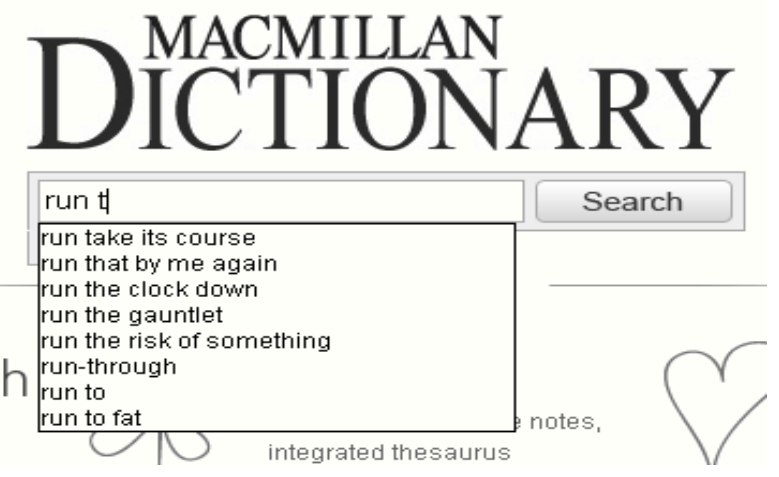

*What makes e-dictionaries effective? - Dictionaries should be able to satisfy those needs within an acceptably short time and with the required degree of detail. In addition, the data have to be presented in a form that is maximally comprehensible. From this it follows that the demands on lexicographic data need not vary dramatically depending on the delivery platform of the dictionary. However, the best lexicographic description will not help the user if it fails to be located, and where e-dictionaries can make a clear difference is in the efficiency of access to lexicographic data, and possibly in the use of multimedia. But electronic dictionaries also form a perfect platform for non-textual media, such as sound, video or animation. Whether and to what extent dictionaries should make use of these modalities ought to be decided on the basis of sound lexicographic principle and evidence of their effectiveness in the specific situations of use, and not by questions of fashion. There is some evidence, sketchy as it is, that not all types of media benefit dictionary users in ways that might be expected.

Dictionaries will be most effective if they are instantly and unobtrusively available during the activities in which humans engage - and ultimately aware of those activities. As more of our work, study and play is done in an ICT-enhanced environment, electronic dictionaries have a chance to blend into that environment by discreetly staying in the background and coming to the rescue when needed. [10. 3-16] In comparison, e-dictionaries have more priorities than traditional dictionaries. The main of them: we would look at the guide words at the top of each page and decide which ones our word would come between in alphabetical order. But in e-dictionary we do it so fast than in traditional dictionary, we can listen to the words definitions sounds but in traditional it is impossible. Firstly, to make dictionaries easier to use, the words are organized in alphabetical order. It is same in e-dictionaries too. From the review of the literature and the analysis of a set of electronic dictionaries, we have synthesized the search techniques in electronic dictionaries in three elements: the query, the resource, and the result. These three elements embody all the search possibilities we have observed in electronic dictionaries. With this classification, we aim to contribute to solving the problems related to nomenclatures, types and subtypes of searches that we have found in each particular dictionary. Clearly, nowadays, electronic dictionaries are frequently used by language learners and the use of these new types of dictionaries is becoming commonplace. However, According to Pastor and Alcina (2010), the ultimate success and achievement in vocabulary learning could not be attributed to 


\section{International Journal of Science and Research (IJSR) \\ ISSN (Online): 2319-7064}

Index Copernicus Value (2013): 6.14 | Impact Factor (2015): 6.391

the use of a specific type of dictionary but to the way they are used by the language learner.

\section{Result}

There has been growing interest in the use of electronic dictionaries for learning foreign languages. Despite students" general acceptance of electronic dictionaries, a great number of English Foreign Language teachers express their concerns over using electronic dictionaries for learning EFL. Several studies have been conducted to evaluate students ${ }^{6}$ perceptions on and attitudes toward the use of electronic dictionaries in educational contexts. For further improvement of the dictionaries, appearances of electronic dictionaries have been resulted in interest of the modern linguistics. In recent years, the numbers of electronic dictionaries have been propagating on network. Keeping more information in these dictionaries have internal users ability even can give anonymous comments and feedback.

\section{References}

[1] Рублева О.С. Дисс. Слово в электронном словаре (с позиций пользователя электронными ресурсами). Тверь, 2010. 168 с.

[2] Чумарина Г.Р. Сравнительная характеристика электронных и бумажных словарей в функциональном аспекте // Вестник Чувашского университета — Чебоксары: Чувашский государственный университет им. И.Н.Ульянова 2009. №4. - c.265-270

[3] Pedro A. Fuertes-Olivera and Henning Bergenholtz (eds.). e-Lexicography: The Internet, Digital Initiatives and Lexicography. 2011. xiv, 341 p. [электронный pecypc] file://D:/ELECTRONIC\%20DICTIONARY/elexsicographer.pdf

[4] Verónica.P, Amparo.A. Search Techniques in Electronic Dictionaries: A classification for translators. International Journal of Lexicography 23(3).2010, p. 307-354,[electronic resourse] URL: www.researchgate.net

[5] Azərbaycan Respublikasında inkişaf naminə İKT-ın tətbiqi və inkişaf etdirilməsinin milli strategiyası (İKTMS). 2003-2012-ci illər. Bak1 2003, [electronic resourse] URL: http://www.tqdk.az, http://www.nicts.az

[6] AMEA-nın İnformasiya Texnologiyaları İnstitutu, sektor müdiri İradə Oləkbərova VİKİPEDIYYA və ONUN İMKANLARI" (mühazirə), səh 7, 2015. ,[electronic resourse] URL: http: // az. wikipedia. org/ wiki/ Lüğət \#

[7] Mahmudov M.A. Computer linguistics. Science and Education, Baki.2013, 366 p

[8] [electronic resourse] URL: www.merriam-webster.com

[9] [electronic resourse] URL: www.ultralingua.com

[10] [electronic resourse] URL: https: // repozytorium. amu. edu. pl Lew, Robert. How Can We Make Electronic Dictionaries More Effective?' In Granger, Sylviane and Magali Paquot (eds.), Electronic Lexicography. Oxford: Oxford University Press. Pre-publication draft. Not for quotation or copying. $20 \mathrm{p}$.

\section{Author Profile}

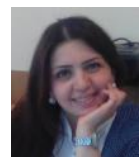

Zhala E. Mammadova is a Ph.D students of Linguistics Institute named after Nasimi of the Azerbaijan National Academy of Sciences. She is studing on her doctoral work named Explanation and Intepretation of words in Electronic Dictionaries". Her specialization is Linguistics. She is working as an English teacher in Sumgait State University. 